\title{
Handling Money: Renter's Insurance ${ }^{1}$
}

\author{
Mary N. Harrison ${ }^{2}$ \\ What You Need to Know
}

Everyone renting an apartment or a house should have renter's insurance. It will protect you against losses from disasters such as hurricanes and fire.

Renter's insurance is moderately priced. You can choose a policy that pays the value of your loss, such as the present value of your furniture. You can choose insurance that pays the replacement value of the loss. Of the two kinds, replacement insurance is the better choice.

Some renters believe the landlord has insurance that protects them. That is not correct. The landlord is not responsible for your loss from fire or other disasters unless the landlord is directly responsible for causing the loss.

Renter's insurance will also protect you in other ways. It helps you when your dog bites a neighbor, or if your child's playmate breaks his arm at your home.

1. This document is FCS5235-03, one of a series of the Department of Family, Youth and Community Sciences, Florida Cooperative Extension Service, Institute of Food and Agriculture Sciences, University of Florida. Publication: May 2002. Revised: December 2005. Please visit the EDIS Web site at http://edis.ifas.ufl.edu.

2. Mary N. Harrison, professor, Department of Family, Youth and Community Sciences, Cooperative Extension Service, Institute of Food and Agricultural Sciences, University of Florida, Gainesville, 32611.

The Institute of Food and Agricultural Sciences (IFAS) is an Equal Opportunity Institution authorized to provide research, educational information and other services only to individuals and institutions that function with non-discrimination with respect to race, creed, color, religion, age, disability, sex, sexual orientation, marital status, national origin, political opinions or affiliations. U.S. Department of Agriculture, Cooperative Extension Service, University of Florida, IFAS, Florida A. \& M. University Cooperative Extension Program, and Boards of County Commissioners Cooperating. Larry Arrington, Dean 